over the environment, Future orientation, Directness / openness / honesty (sincerity, sobriety, straightforward, frankness, earnest, etc.), American liberalism and capitalism, Informality и т. п.

Ключевые слова: система ценностей, номинативное поле, вербализаторы концепта, ядерная зона, околоядерная зона, периферийная зона.

Svitlikovska Olena. Verbalizers of the Concept «VALUES» in the American Linguoculture (Based on Massmedia Texts). The article investigates the system of values in the American linguoculture through the VALUES concept. We divide the key values into the following main groups: vital, social, political, moral, religious and ideological, artistic and aesthetic, family and labor values. The nominative field of the VALUES concept is created on the basis of linguistic means that reveal it. The structure of the nominative field of the concept is represented by the nuclear and its periphery, which include the meaning of a certain lexeme, introduced by a hyperseme / hypersemes. This higher order semantic component organizes the development of the semantic field around itself. To establish the nuclear of the VALUES concept nominative field in the American media discourse, the definitions of a key lexeme, as well as related lexemes were traced in dictionaries and thesauruses. The analysis of lexicographic sources represented a synonymic expansion of the key lexeme and related units. The following socio-cultural values of the American society were singled out: personal control over the environment; change; time and its control; equality / egalitarianism, individualism; privacy; individual achievement (status, success); self-reliance / independence; competition; future orientation; action / work orientation; informality; directness / openness / honesty; patriotism, etc. The frequency usage analysis of the key lexemes and their synonymic extension is carried out. It is established that the nuclear of the VALUES concept includes Action / Work orientation component. The perinuclear area consists of the following notions: Equality / Egalitarianism, Time and its control, Change, Individual achievement (status, success), Materialism / Acquisitiveness (possess(iveness), consume(rs), customer (s), goods, services), Privacy, Value (s), etc. The peripheral area of the VALUES concept is the following: Practicality, Individualism, Competition, Personal control over the environment, Future orientation, Directness / openness / honesty (sincerity, sobriety, straightforward, frankness, earnest, etc.), American liberalism and capitalism, Informality, etc.

Key words: value system, nominative field, concept verbalizers, nuclear area, perinuclear area, peripheral area.

DOI: https://doi.org/10.32782/2410-0927-2020-13-23

УДК 821.111-34:81’22

Алла Слащук

\title{
ЗНАКОВІСТЬ ЯК НЕВІД'СМНИЙ ЕЛЕМЕНТ ЖАНРУ АНГЛІЙСЬКОЇ ЛІТЕРАТУРНОЇ КАЗКИ
}

У статті описано результати дослідження стосовно знаковості як невід'ємного елементу жанру англійської літературної казки. Зокрема, висвітлено питання декодування мовного знаку, де знак, репрезентований певною дією чи ситуацією, представляє при цьому інше поняття або явище. Окрім того, проаналізовано семіотичний простір літературної англомовної казки. Установлено, що семіотична система дає змогу об'єднати вигадку, категоріальну ознаку казки, та іï знакову природу. Схарактеризовано значення семіотики у вивченні казкового оповідання. Установлено перспективність дослідження літературної англомовної казки як такої, що стає ще більш художньою, i, як наслідок - більш образною й символічною, де побутові подробиці трапляються поряд із фантастичними явищами. Репрезентовано визначення літературної казки як такої, що має здатність поєднувати реальне та чудесне, зближуючи літературну казку із життям, тим самим створюючи основу для дослідження семантичної ускладненості казкового оповідання й розгляду авторської ідеї на різних рівнях інтерпретації. Проаналізовано важливість трилатеральності знаку, де, окрім єдності плану вираження та плану змісту, третім елементом представлено читача, котрий отримує інформацію шляхом декодування значення знаку, що трапляється в тексті казки. Розглянуто класифікацію знаків Ч. Пірса задля виділення саме тих, що наявні в літературній казці, і можливість їх взаємодії. Отже, виокремлено індексальні знаки, а саме знаки-симптоми та знаки-кінеми, а також подано їх дефініції. Так, симптоми представлено саме умовними знаками для читача, які наділені імпліцитним характером, певними характерними ознаками, що дають додаткову інформацію й наповнюють текст емоційним складником, тоді як знаки-кінеми є конвенційними, свідомими жестами чи мімікою, які несуть «парасемантичне значення». Проілюстровано й доведено індексальність літературної казки, де знаки є можливими засобами передачі не лише умовної поведінки та причинно-наслідкових зв'язків, а й прихованого змісту емоційного стану персонажів.

Ключові слова: семіотика, знаковість, знак, індексальність, кодованість, знак-симптом, знак-кінема, англійська літературна казка.

Вступ. Останнім часом у працях вітчизняних лінгвістів спостерігаємо зацікавленість семіотикою. Учені, аналізуючи мовні засоби, що виконують породження, передачу та збереження інформації про навколишній світ і суспільство, визнають, що успіх комунікації

(C) Слашук А., 2020 
багато в чому залежить від іï семіотичного забезпечення, тобто від того, якою мірою вдалося виразити потрібну інформацію в знаковому вигляді. Семіотика опирається на поняття знаку як на певне явище чи предмет, репрезентуючи при цьому якийсь інший предмет, явище або ситуацію. Виявлення значення, яке зашифроване в знаковому повідомленні, відбувається шляхом декодування, де код означає спосіб упорядкування знаків у певну систему, завдяки якій відбувається комунікативна функція мови $[1 ; 7]$. Таке розуміння семіотики дає змогу застосовувати семіотичний підхід у ході аналізу творів казкового жанру. За допомогою знакової системи читач співвідносить певні елементи з відомих йому фольклорних чи міфологічних сюжетів із матеріалом літературної казки. Інколи, такі «знаки» не лежать на поверхні, а $\epsilon$ завуальованим відображенням певного символу чи культурного коду.

У формуванні семіотики як науки було багато не лише цікавого, але й дискусійного, що зумовлено різноманіттям семіотичних ідей, основні з яких сформовано ще в XIX ст. Ядро семіотичної теорії становили праці Ф. де Соссюра, Ч. Пірса, Ч. Морріса, Р. Якобсона та ін. Положення, розроблені цими ученими, хоча й відрізнялися між собою за деякими аспектами, залишаються актуальними й сьогодні [2]. Найчіткіше нові дослідницькі принципи знаковості викладені Ф. де Соссюром у «Курсі загальної лінгвістики»[2]. Сутність мовного знаку автор визначає таким чином: «Мовний знак пов'язує не річ та іiі назву, а поняття та акустичний образ» [9, с. 69]. О. С. Кубрякова, аналізуючи семіотичні ідеї Ч. Морріса, стверджує, що під актом семіозису треба розуміти пошуки такої мовної форми, яка оптимально співвідносилася б із цим змістом. Таку ціль, на думку О. С. Кубрякової, мають словотвірні акти, і більшість нових словесних знаків, що з'являються на цьому етапі, пов'язані зі словотвором. Слова рідко «вигадуються» просто так, і їх вивчення як актів семіозису є найдоцільнішим, тому що життя слова в системі мови зумовлюється його місцем у цій системі як системі знаковій, семіотичній [6, с. 245].

Основна мета статті - проаналізувати роль знаку та можливість його функціонування в тексті англомовної літературної казки для дорослих. Завдання дослідження - провести аналіз тексту літературної англомовної казки для виявлення ролі знаків-індексів у структурі казкового оповідання.

Методи та методики дослідження. Для розв'язання поставлених завдань використовували методологічні засади про мову як спосіб відтворення дійсності, про кореляцію умовних індексальних знаків й англійської літературної казки. Загальнонаукова методологічна основа дослідження грунтується на засадах антропоцентризму як домінантного дослідницького принципу, який визначає розвиток сучасної гуманітарної науки. У процесі написання статті застосовували такі методи й методики дослідження, як описовий, метод суцільної вибірки, елементи семіотичного та лінгвосеміотичного аналізу. Семантичний аналіз мовних одиниць здійснювався на основі тлумачних словників (Macmillan Dictionary, Oxford English Dictionary).

Результати та дискусії. Семіотика може використовуватись як універсальний підхід у різноманітних сферах знання, в яких застосовуються такі категорії, як знак, модель, система. Мовні знаки містять у собі як образи інших знаків, так і образи дій із цими знаками, а отже, i образи реальності, що пояснюються за допомогою цих знаків [4, с. 24]. Семіотична система допомагає об'єднати вигадку, категоріальну ознаку казки, і ії знакову природу. Семіотичні основи літературної казки спроможні не лише відображати звичну дійсність, а й породжувати вигадану казкову реальність, яка $\epsilon$ впізнаваною моделлю світу й створює достовірність казкового твору. У нашому дослідженні йдеться саме про літературну казку як таку, що володіє особливим психологізмом у зображенні персонажів, котрі перетворюються в героїв, внутрішній світ яких є багатим, а переживання - глибокими. На думку О. М. Ковтун, «...літературні казки намагаються максимально наблизити фольклорні канони до сучасних естетичних норм, ускладнити традиційний казковий та міфологічний конфлікт, пов'язати «вічні» метафори $\mathrm{i}$ символи з психологічними контекстами сучасної людини» [5, с. 176].

Сьогодні літературна казка стає ще більш художньою i, як наслідок -більш образною та символічною. Побутові подробиці трапляються поряд із фантастичними явищами, а таке поєднання реального й чудесного зближує літературну казку із життям.

Враховуючи загальноприйняту думку, маємо згадати, що ХX ст. представляє період розквіту цього жанру, а в кінці цього ж століття, в епоху постмодернізму, виникає новий інтерес 
до літературної казки. Автори цього періоду демонструють можливість пізнання світу через міф, фантазію та казковість. Дослідники відзначають, що сучасна літературна казка «запозичує досвід інших жанрів - роману, драми, поезії. В літературній казці схрещуються елементи казки про тварин та чарівної казки, пригодницької та детективної повісті, наукової фантастики та пародійної літератури. Така казка $\epsilon$ багатошаровою, казкою різних рівнів. Одним 3 їі компонентів може бути і наукова гіпотеза, і оповістка, і повір'я, i сага, і легенда, і приказка, i дитяча пісенька, літературний твір, а інколи і те, й інше у поєднанні» [3, с. 76]. Потрібно зазначити, що жанр сучасної казки містить поєднання типів та стилів казкового оповідання та фантастичної літератури, що впливає на створення семантичної ускладненості казкового оповідання й передбачає розгляд авторської ідеї на різних рівнях інтерпретації. Саме тому матеріалом для нашого дослідження обрано збірку історій "Little Black Book of Stories" («Маленька чорна книжечка історій») (2004) англійської письменниці Антонії Баєтт (1936 - ), Дами - Командора ордену Британської імперії, яка отримала Букерівську премію за роман Possession (1990).

Теорія Ч. Пірса, на нашу думку, є важливою для того, щоб розглянути класи знаків і їх різновиди задля виділення саме тих, що трапляються в літературній казці, та можливість їх взаємодії. Ця теорія також важлива для цього дослідження, оскільки, окрім самої мови та смислового навантаження, яку вона несе, передбачено присутність третього елемента - читача, котрий отримує інформацію шляхом декодування значення знаку, що трапляється в тексті казки. Як зазначає О.Д. Огуй: «Знаки $\epsilon$, поза сумнівом, мотивованими, структурними та функціональними». За Ф. де Соссюром (F. De. Saussure 1949), знак білатеральний завдяки єдності плану вираження та змісту. Грунтуючись на принципі бінарної опозиції у традиційній лінгвістиці звично використовують дихотомію (аналітичний поділ явищ лише на дві складові частини без урахування їх синтетичної єдності) як прийом дослідження. Структурна дихотомічна концепція знака як єдність плану змісту й форми, що не в змозі пояснити деякі прагматичні, когнітивно-дискурсивні феномени, має поступитися щонайменше трихотомічній концепції, де основу становить людина як деміург знакотворення. За Ч. Пірсом (Ch. Pierce 1867) та К. Бюлером (див. його «Органон») знак можна вважати тристоронніми (трилатеральним), оскільки його форма та зміст доповнюється ще й людською діяльністю (як sign-maker «продуцент знака»)» [8, с. 24]. Як бачимо, у полікоординатному погляді на мову все більшу увагу привертає теоретична спадщина Ч. Пірса у форматі новітніх процесів теоретичної переорієнтації світової лінгвістики. Класифікація знаків Ч. Пирса полягає в їх поділі на три основні класи: знаки-ікони, знаки-індекси та знаки-символи. Усі вони, відповідно, виражають три ступені семіозису: метафоричний (знаки-ікони), метонімічний (знаки-індекси) та конвенційний (знаки-символи) [7, с. 130]. У нашому дослідженні пропонуємо зосередити увагу на дослідженні індексальних знаків, а саме на одних з їх різновидів - знаках-симптомах, i їх відображенні в жанрі англійської літературної казки.

Симптоматичні індекси $є$ частиною героя, існують разом із ним та можуть виражати його психічні й емоційні прояви, його жести та міміку. Це, так звані, орієнтири, які спроиожні виражати причинно-наслідкові зв'язки. Вони перебувають у метонімічних відносинах зі своїми об'єктами, на які й указують. Іншими словами, усі емоції, які переживають казкові персонажі (радість, горе, смуток, вдячність, страх та ін.), можуть легко розпізнаватися читачем і мають універсальне значення. Жести та міміка $\epsilon$ значимими у відображенні емоційних станів персонажів. Читач завжди намагається зрозуміти, що означає той чи інший жест чи погляд, які насичені «парасемантичним значенням» [7, с. 136].

Сам читач може співпереживати герою, тим самим запевнюючи себе, що казкові персонажі - справжні живі люди, що посилює достовірність казкової дійсності. Симптоми - це саме умовні знаки для читача, які наділені імпліцитним характером; певні характерні ознаки, що дають додаткову інформацію й наповнюють текст емоційною складовою.

Проте, розглядаючи відображення таких семіотичних знаків у полі літературної казки, маємо розрізняти знаки-симптоми та знаки-кінеми.

Так, Н. Б. Мечковська диференціює їх таким чином: «знаки-симптоми (тобто ознаки тих чи інших станів) - це психологічно значимі пози, жести, мімічні рухи, зовнішні звукові та 
«колірні» прояви психічних станів» [7, с. 137]: turn red in the face (from anger), blush (with shame), blanch with terror, smn. keeps going hot and cold (with shame), grow cold with terror, one's heart sank (from fear), to scratch oneself, to wink, to feel/have a pain. Знаки-кінеми - «це комунікативно значимі рухи тіла, жести та мімічні прояви, які використовуються в якості узуальних поведінкових актів» [7, с. 137]: to nod, to shake one's head, to shake one's fist at smb., to put out one's tongue (at smb), to give the screw-loose sign. Знаки-кінеми, на відміну від знаків-симптомів, які ненавмисні, виконуються свідомо та мають адресата.

Жести є проявом психосоматичного стану людини за характером зв'язку форми й змісту, які, зі свого боку, дають змогу здогадатися про значення тієї чи іншої кінеми, навіть не бачучи ії, тим самим створюючи так звану конвенційність між героєм і читачем.

Знаки-симптоми спроможні відобразити особливу атмосферу та настрій казкового твору. За допомогою міміки й жестів такі знаки імпліцитно передають емоційний стан героя. Наведемо приклади з казки “The Thing in the Forest” («Дещо в лісі») із раніше згаданої збірки казок "Little Black Book of Stories” («Маленька чорна книжечка історій») англійської письменниці Антонії Баєтт:

"The only sounds - from all parts of the great dormitory it seemed - were suppressed snuffles and sobs, from faces pressed into thin pillows" (10, p. 9).

Маленькі герої казки, опинившись далеко від дому без батьків у незнайомому середовищі, відчувають страх та одинокість. У представленому прикладі немає лексичних одиниць, які виражають емоції дітей експліцитно. Проте там є знаки-симптоми, які допомагають читачу розпізнати горе дітей. Словосполучення 3 негативним емоційним забарвленням, яке виражене сопінням і схлипуванням (suppressed snuffles and sobs), вказує на дитячі переживання. Плач симптом горя, смутку є природньою реакцією маленької дитини на дискомфорт і переживання. Жестовий знак, де маленькі герої лежать обличчями в подушку (faces pressed into thin pillows) підкреслює одинокість та страждання героїв. Цей приклад ілюструє переживання драматичних моментів двох маленьких дівчат Пенні й Прімроуз, які були змушені розлучитись із домівкою та своєю мамою через масові бомбардування Лондона в період Другої світової війни.

Наступний приклад ілюструє знак-кінему, де тримання за руки один одного (held hands) $є$ конвенційним жестом довіри й дружної підтримки, яку дівчата проявляють одна стосовно одної:

"Penny and Primrose held hands, and said to each other that it would be wizard if they could go to the same family, because at least they would have each other" $(10, \mathrm{p} .7)$.

Цікавим $є$ наступний приклад, де ми спостерігаємо поєднання знаків-симптомів і знаківкінем:

"When it had gone, Penny and Primrose, kneeling on the moss and dead leaves, put their arms about each other, and hugged each other, shaking with dry sobs" (10, p. 17).

Знаки-симптоми тут указують на емоційне потрясіння дівчат після з зустрічі з чимось незвіданим для них. Це «щось» залишило їх живими та неушкодженими й дівчатка відчувають полегшення, яке зображується кінемою міцних обіймів (put their arms about each other, and hugged each other), а шок і страх від жахливої зустрічі виражені симптоматичним знаком схлипувань тремтячих дітей (shaking with dry sobs). Дієприкметник (kneeling) підсилює ідею потрясіння, яке перенесли Пенні та Прімроуз і яке обезсилило їх настільки, що вони були змушені опуститися на землю.

Висновки. Отже, проведене дослідження дає підстави для висновку про те, що характерні особливості жанру літературної казки, як «кодованість» казкового оповідання, знаковість казкових персонажів і ситуацій, у яких вони опиняються, їх впізнаваність та універсальність, наявність вигадки, яка грунтується на принципах аналогії, асоціації та гри, установлюють певні закони, за якими створюється казкова умовність та сформовані вигадкою ефекти. Названі вище особливості жанру літературної казки дали підставу стверджувати, що казкове оповідання може бути введене у світ семіотики, науки про знаки (класи й види знаків). Лінгвосеміотичний аналіз індексальних знаків у тексті сучасної літературної казки відкриває перспективи для подальшого розгляду інших класів знаків і їх функціональних особливостей у жанрі літературної англомовної казки. 
2. Borodulina, Nataliya. 2008. "O roli semiotiki v issledovanii yazykovykh znacheniy". Filologicheskiye nauki. Voprosy teorii i praktiki 1: 18-20.

3. Braude, Lyudmila. 1979. Skandinavskaya literaturnaya skazka. Moskva: Nauka

4. Byalyk, Vasyl. 2012. Epistemolohiya leksychnoho kvantora: monohrafiya. Chernivtsi: Zoloti lytavry.

5. Kovtun, Yelena. 1999. Poetika neobychaynogo: Khudozhestvennyye miry fantastiki, volshebnoy skazki, utopii, pritchi i mifa (Na materiale yevropeyskoy literatury pervoy poloviny XX veka). Moskva: Izd-vo MGU.

6. Kubryakova, Yelena. 2004. "O semioticheskikh osobennostyakh proizvodnogo". Semiotika, lingvistika, poetika: $k$ stoletiyu so dnya rozhdeniya A. A. Reformatskogo 243-249.

7. Mechkovskaya, Nataliya. 2008. Semiotika: Yazyk. Priroda. Kultura. Moskva: Izdatelskiy tsentr «Akademiya».

8. Ohuy, Oleksandr. 2012. "Linhvistychna teoriya znaka v epistemolohichnomu rakursi". Visnyk Zhytomyrskoho derzhav. universytetu im. I. Franka 62: 22-26.

9. Sossyur, F. de. 1998. Kurs zahalnoyi linhvistyky. Kyyiv: Osnovy.

10. Byatt, Antonia. 2004. Little Black Book of Stories. Surrey: Vintage, Bookmarque Ltd., Croydon.

11. Macmillan Dictionary. URL: http://www.macmillandictionary.com

12. Oxford English Dictionary. URL: http://www.oed.com

Слащук Алла. Знаковость как неотъемлемый элемент жанра английской литературной сказки. В статье описываются результаты исследования знаковости как неотъемлемого элемента жанра английской литературной сказки. В частности, освещаются вопросы декодирования речевого знака, где знак, представленный определенным действием или ситуацией, передает при этом другое понятие или явление. Кроме того, анализируется семиотическое пространство литературной англоязычной сказки. Устанавливается, что семиотическая система помогает объединить выдумку, категориальный признак сказки и ее знаковую природу. Дается характеристика значения семиотики в изучении сказочного повествования. Устанавливается перспективность исследования литературной англоязычной сказки как таковой и ее становления как более художественной, и как следствие - более образной и символической, где бытовые подробности встречаются бок-о-бок с фантастическими явлениями. Определяется литературная сказка, которая имеет способность сочетать реальное и чудесное, сближая литературную сказку с жизнью, тем самым создавая основу для исследования семантической усложненности сказочного повествования и рассмотрения авторской идеи на разных уровнях интерпретации. Анализируется важность трилатеральности знака, где, кроме единства плана выражения и плана содержания, третьим элементом представлен читатель, который получает информацию путем декодирования значения знака, что встречается в тексте сказки. Рассматривается классификация знаков Ч. Пирса с целью выделения именно тех, которые встречаются в литературной сказке, и возможность их взаимодействия. Таким образом, выделены индексальные знаки, а именно знаки-симптомы и знаки-кинемы и формулируются их дефиниции. Так, симптомы представлены именно условными знаками для читателя, которые наделяются имплицитным характером, определенными характерными признаками, которые дают дополнительную информацию и наполняют текст эмоциональной составляющей, тогда как знакикинемы являются конвенциональными, сознательными жестами или мимикой, что владеют «парасемантическим значением». Иллюстрируется и доказывается индексальность литературной сказки, где знаки являются возможными средствами передачи не только условного поведения и причинно-следственных связей, но и скрытого содержания эмоционального состояния персонажей.

Ключевые слова: семиотика, знаковость, знак, индексальность, кодированость, знак-симптом, знак-кинема, английская литературная сказка.

Slashchuk Alla. Remarkability as an Integral Element in the Genre of English Literary Fairy Tale. The article describes the results of a study devoted to remarkability as an integral element in the genre of English literary fairy tale. In particular, the issues of decoding of a speech sign have been highlighted where a sign, represented by a certain action or situation, conveys another concept or phenomenon. In addition, the semiotic space of English literary fairy tale has been analyzed. Thus it has been determined that the semiotic system helps to combine fiction, a category feature of a fairy tale, and its symbolic nature. The significance of semiotics in the study of a fairy tale narrative has been characterized. The article studies the perspective of research of a literary fairy tale as it becomes more fictional and, as a consequence, more figurative and symbolic where everyday details are side by side with fantastic phenomena. The definition of a literary tale has been represented. It has been outlined that this kind of tale can combine the real and the miraculous, bringing the literary tale closer to life, thereby creating the basis for studying the semantic complexity of the fairy tale narrative and considering the author's idea at different levels of interpretation. The importance of trilaterality of a sign has been analyzed, where, in addition to the unity of the plane of expression and the plane of content, the third element is a reader who receives information by decoding the meaning of the sign that occurs in the text of a fairy tale. It has been considered the classification of signs by Charles Peirce to highlight the ones that are found in a literary tale and the possibility of their interaction. Thus we have defined index signs, namely, signs-symptoms and signs-kinemes. The symptoms are represented as conventional signs for readers which have an implicit character and fill the text with emotional component, while kinemes are conventional, conscious gestures or facial expressions that have a "parasemantic meaning". It has been illustrated the indexicality of a literary tale, where signs are the possible means of expressing not only conventional behavior, but also the hidden content of the emotional state of characters.

Key words: semiotics, remarkability, sign, indexicality, coding, sign-symptom, sign-kineme, English literary fairy tale. 